\title{
Political Accountability in Appointments to the Supreme Court of Canada
}

\author{
John D Whyte*
}

There are good reasons to consider a regime for parliamentary review ${ }^{1}$ of persons who have been proposed for appointment to the Supreme Court of Canada. ${ }^{2}$ Although the Supreme Court is the final court of appeal for all legal disputes and, therefore, has an important role in the clarification and development of Canadian private law and administrative law, the primary ground for urging parliamentary review ${ }^{3}$ of persons named for appointment is the importance of the Court's constitutional decisions (and its opinions in constitutional references) to Canada's political environment. ${ }^{4}$ The Supreme Court of Canada serves as Canada's "constitutional court" and the effective power of appointment to it rests with the Prime Minister. ${ }^{5}$ This may be too significant a power to leave to the head of the executive branch to exercise unilaterally; it is a power insufficiently circumscribed in light of the national social and political influence of the Supreme Court. ${ }^{6}$

As a remedy to outsized power being given to the Prime Minister, there should be hearings held before a parliamentary committee at which committee members listen to the person who has been proposed for appointment to the Court speak of his or her record of achievement, his or her views of judicial decision-making, and his or her ideas about the national purposes that are advanced by the Constitution, and subsequently put to that person questions about such things as professional and life experiences, moral bearings, ideas on the adjudicative process and basic ideas about the good state. Such hearings would at least be a pre-emptive check against the appointment of the facile, the glib, the dogmatic, the egotistical, and those insensible and insensitive to the social realities of living ordinary lives in this nation.

There are many issues related to the method and formal structure of a hearing process. There are also legitimate concerns about the damage that might be done to the Supreme Court or the judicial branch generally by hearings, chiefly the risk of political partisanship in the review process, which might be perpetuated through politically partisan conflict among the members of the Court. Neither the issues of implementation nor strategies for reducing the risks of injuring the Supreme Court's reputation or eroding confidence in the legal process through coarse politicization of a hearing process are addressed in this paper, although they are hardly insignificant concerns. The matters discussed in this article are, first, the case for instituting legislative hearings and, second, assessing the value of hearings in terms in light of the types of questions that can properly be explored in hearings before a parliamentary committee.

\section{Seeking political accountability in Supreme Court appointments}

The impetus for adding legislative hearings to the current statutory arrangement for making appointments to the Supreme Court is a conse- 
quence of the adoption of the Canadian Charter of Rights and Freedoms into Canada's Constitution in $1982 .^{7}$ While the structural relationships between courts and political branches of government were not altered or, from a formal perspective, expanded by the introduction of the Charter into the Canadian Constitution, the popular grasp of the nature of this relationship has grown considerably since the inclusion of human and political rights in the Constitution and, as a consequence, the Court's engagement with legal issues that touch on moral sensibilities and societal values. This increase in the scope of the Court's supervision of legislative policy and executive administration has produced a popular understanding of the enhanced capacity of the Court to interfere with choices that have been made through political processes. ${ }^{8}$ Awareness of the Court's role has been increased by the frequent claim that the Charter's impact on exercises of political powers is a threat to the democratic foundation of Canadian political legitimacy because it has granted courts new bases for nullifying the laws and policies of democratically elected legislators and the actions of the democratically chosen executive branch. The theme of the judicialization of political discretion has become a leitmotif of Canadian constitutional scholarship since $1982^{9}$ and has served to underscore public awareness of the significance of the Court. In addition, there is frequent evidence that courts do strike down, or modify, legislatively created programs of wide social interest. All of this has served to underscore the political importance of courts' constitutional decisions. ${ }^{10}$

As significant as the adoption of the Charter of Rights and Freedoms has been in bringing public attention to the Supreme Court and its influence on the policies and actions of Canadian governments, the political effect of, if not popular sensitivity to, judicial review of governmental action has been a factor of Canadian governance over the century and a third of Canada's constitutional regime. There is a long record of legal accountability for Canada's democratically elected governments based on the rule of law - on the limits placed on governmental authority found in statutes, the Constitution and case law. Furthermore, the idea of judicial supervi- sion of governmental action is a far older legal development than its presence in the Canadian system of constitutional government or, even, in liberal democracy. ${ }^{11}$ A pivotal point was adding the practice of controlling legislatures through application of the legal limits set out in a written Constitution to the dominant electoral conception of democratic theory. Commonly, credit for this highly significant structural development is given to Chief Justice John Marshall of the United States Supreme Court. ${ }^{12}$ Within Canada, it could just as well be given to Chief Justice Ritchie of New Brunswick in The Queen $v$ Chandler ${ }^{13}$ for his recognition of the necessity of a Canadian practice of judicial review of legislation - not based so much on the imperial arrangement of testing for the validity of Canadian legislation under the Colonial Laws Validity Act, $1865^{14}$ but, rather, resting judicial determinations of consistency with the Constitution on the more deeply rooted ideas of the rule of law and ultra vires. ${ }^{15}$

Because constitutional review on the political capacity of Canadian legislatures and governmental agencies has been controversial from time to time, it has placed the role of courts especially final courts of appeal - under public assessment, not just through critical analyses by constitutional scholars, ${ }^{16}$ but occasionally through reactions of elected political leaders. From judicial reading down of the expected (at least, in some political quarters) large scope of the "peace, order and good government" and "trade and commerce" clauses, to judges placing limits on the power of legislatures to create new administrative structures, to judicial interpretations that limit provincial regulatory and taxation powers (most visibly with respect to the regulation of provincial natural resources ${ }^{17}$ ), judicial decisions have engendered political notice. Canada's constitutional jurisprudence has been a continuous element of Canadian democratic governance, although not always a widely conspicuous one.

It seems clear that those responsible for the 1867 Constitution did not anticipate the degree to which judicial supervision of the actions of the political branches would occur. While the rule of law notion in the period prior to Confederation 
was clear and fully rooted in the legal culture, it was likely not anticipated to be a legal principle that would forcefully impact governments' political programs and ambitions. ${ }^{18}$ The method of appointing superior court judges, ${ }^{19}$ including, later, judges of the Supreme Court of Canada, would not have been thought to be unduly influenced by governmental interests, nor so caught up in political calculation that it would lead either to impairment of the intellectual function of legal judgment or to significant distortion of legal standards in order to serve political interests. In any event, court decisions that dealt with questions of governmental capacity and authority were expected to be well-constrained; midnineteenth century views on legal judgment were based on confidence in the broad intellectual separation between making legal judgments and weighing social and political interests or values. Although it has long been recognized that law, at the point of application, is mostly indeterminate, its dispositive effect was once more attributed to largely determined correct applications of established rules than to fleshing out the normative weight of laws' underlying social purposes, or to the linking of laws' applications to their moral provenance.

However, the marked increase in the effect of the Court's decisions on politically constructed social arrangements has been produced by the introduction of the Charter and it is this increase that leads to the claim that the power to make appointments to the Supreme Court of Canada should be re-constructed so that they can be made subject to a process that offers a more robust degree of political accountability. ${ }^{20}$ Increased public awareness of the impact of the Supreme Court's constitutional adjudication on different social and personal interests has given the appointment process broader political visibility and importance. As a matter of conventional design in liberal democratic states, the exercise of significant political powers - making decisions of "high politics" and structural significance - should be made subject to checks and restraints through a structure of direct accountability, which can be accomplished most effectively in the form of a coordinated decision process.
There are additional incentives for creating greater political accountability for Supreme Court appointments. One of these arises from changes in the practice of politics and the influence of political loyalty. The once-confident assessment that granting the Cabinet full power to appoint persons to the judiciary, including to the nation's final court of appeal, would produce good results was possibly a reflection of a general political understanding of the duty to preserve the integrity and efficacy of the organs of government so that the virtues that were, as a constitutional design, sought for them would be heeded in making appointments. When there is agreement on the institutional virtues that need to be maintained in making political choices, especially choices bearing on institutional capacity, there is, under the theory of preserving institutional integrity, less need for countervailing checks on the exercise of powers. Under a general subscription to the conserving conception of political power, unilateral executive power over judicial appointments represents a low risk to the integrity of the judicial branch.

When political practice becomes less principled and less institutionally idealistic and public confidence in the commitment to exercising power to preserve institutional integrity wanes, it seems wise to reform political structures to provide a check against self-favouring exercises of power. If the political imperative becomes a constant search for partisan advantage, and commitments to institutional purposes are compromised through intensified factionalism, and when this flavour of politics reaches into the composition of the national supreme court, it is prudent to make renovations to the exercise of constitutional powers so that ethical assumptions lying behind constitutional arrangements might be more readily preserved.

It seems, however, that the initial Canadian experimentation with parliamentary hearings for persons named for appointment to the Supreme Court ${ }^{21}$ did not come about due to specific anxiety about questionable appointments. It may, however, have been prompted by an abstract anxiety about parliamentary government and about the risks of ruthless majoritarian 
rule that that inevitably lurk within its structures. Power wielded under the influence of political dogmatism by a parliamentary majority can be as destructive of the instruments of government, including the rule of law, as can be any other form of illiberalism.

There is a further case for a form of legislative approval of appointments to a nation's supreme court based on the idea that the courts' role in ensuring accountability for the decisions of government is an essential element of liberal democracy. Acceptance of the need for a court role in regulating state action depends on political confidence in the integrity of courts and their decision making. If the sole political engagement with the formation of a nation's highest court comes from the party with power to appoint judges, then the sense of political confidence in that court will be weaker than it needs to be. In democracies that, unlike Canada, are struggling to adopt government under a constitution, shifts in the holding of undiluted power may lead to claims of lack of judicial legitimacy when new political leaders come to power. Judges appointed to a national supreme court through the participation of only those holding political power may be characterized as favouring factional political interests, and, in extreme circumstances, may not survive the shift in governmental power. While this may seem an unlikely scenario in developed democracies, all evidence suggests that mature democracies, too, easily descend to destructive partisanship. If the issues a court is called on to resolve grow closer to questions of the permissible scope of political authority and more engaged with social beliefs that have foundational meaning - or, even, existential meaning - for individuals and minorities, the prudence of having broader political endorsement of judges and courts is more evident. Legislative hearings are a structural adaptation that promotes broader political connection to nations' supreme and constitutional courts.

Finally, legislative review of Supreme Court appointments can produce the political dividend of public understanding of both the role of the Court and the distinctive nature of judicial decision-making, especially of constitutional deci- sion-making. ${ }^{22}$ Of course, any political process can lead to the perverse effects of disillusioning the general population and producing cynicism about claims of virtue that are typically made for political debate. This may be particularly true with placing the selection of judges within a regime that can give rise to political contestation. What may emerge from vehement party support for, or vehement party opposition to, an appointment is the belief that what is truly at stake for those reviewing the nomination is not the intelligence, skill or integrity of nominated persons, but rather his or her reliability as a representative of the political views of the political parties in conflict over the appointment. This possibility needs to be resisted, first, through the creation of a parliamentary norm of non-partisanship in performing this review function and, second, political belief in the democratic value of letting citizens see, through the experience of legislative hearings, that in interpreting and applying the constitution there is an intelligible intellectual process of matching governmental decisions to constitutionally established relationships, commitments and purposes - that there are constituted principles of statecraft that represent the national ideals of justice and accommodation that, through law, bind governments.

\section{Scope of legislative review: constitutional adjudication}

In "Appointment of Thomas A. Cromwell to the Supreme Court of Canada," ${ }^{23}$ Peter Hogg asserted that: “... the majority of the court's case load is non-constitutional law ... . These cases may not be as important to the public policy of the country as constitutional cases but the parliamentary committee is aware that the judges have to decide the non-constitutional cases wisely too." ${ }^{24}$ It is correct that constitutional cases do not form a majority of the Supreme Court's caseload and, also, that non-constitutional cases need to be decided wisely. $\mathrm{Bu}$, in 2015 , for example, one third of the Court's decisions were in constitutional cases. This represented the Court's most active area of decision-making. It was the area of Court activity that produced virtually all the public attention that was paid to Court decisions. 
Charter decisions give rise to extensive public discourse and debate over their implications for Canadian society. It was the Court's role in mediating between challenged legislative measures, or their application, and individuals' and minorities' Charter claims that captured both political and popular interest in the Court's work. Over the post-Charter period it is clearly constitutional litigation that has led to broad public engagement with who is appointed to the Court.

A more profound case for legislative hearings for persons nominated for appointment is the opportunity for public discourse over legitimate sources in constitutional adjudication and the chance to explain constitutional interpretation (and, perhaps, to save it from the unhelpful analogy of baseball umpires calling strikes and balls). The constitutional text, whether the 1867 text or the 1982 text, has, to a considerable extent, been constructed around the goals of stability and justice - and stability through justice - as well as current ideas of public interest and personal entitlements. A jurisprudential ideal is that the realization of basic constitutional goals - and the constitution's specific ideas of justice for individuals and communities - must be worked out through contemporary discernment of the nation's current needs in light of the commitments and ideas of justice that shaped national formation and led to the constitutional text. ${ }^{25}$ Ideas of constitutional justice should be recognized in adjudication as having normative significance. This normative significance is captured by the idea of keeping faith with our past, not by the replication of it, but through understanding its ideas of justice and seeking to bring those ideas into our current conflicts.

Cultivating this understanding entails an intellectual process that relies on prudential insight and moral understanding as judges seek out the normative weight of the words of the constitutional text and precedents for specific contexts before them. In addition to a process for examining such things as the strength of a candidate's jurisprudential understanding and his or her capacity to understand the moral climate, a hearing can bring out the ability of a candidate for appointment ability to recognize his or her perceptions of social conditions and to have the humility to hold on to perceptions and beliefs tentatively and presumptively only. The process of legislative committee review of both character and the intellectual commitment to understanding and explaining the nature and process of constitutional application should influence governments to nominate to the Supreme Court persons with large minds capable of discerning and describing the processes for applying the statutory and constitutional rules of public ordering.

Legal interpretation of constitutions, statutes and prior decisions shapes justification for judicial determinations. Such justifications are hardly based on the sense that legal texts are so self-prescriptive that judicial construction of meaning is not necessary. One role for legislative hearings is exploration with the nominated person of the types of interpretive strategies that judges adopt. This process can shed light on the sources and the nature of judicial conflicts and illuminate what is behind shifts in constitutional outcomes over time. This exploration of intellectual shades in judging can lead to a more sophisticated understanding in legislators and the public of how basic ideas about interpretation produce different conceptions of the limits of governmental action. To place before the population through public legislative hearings the idea that legal judgment, and constitutional judgment in particular, relies on ideas of the state - ideas that limit the state or compel the state with respect to dealings with individuals and minorities - helps carry forward the most basic aspiration of democratic political power, which is to enable citizens to become engaged with the discussions that explore the nation's idea of doing justice.

A basic claim about judicial adjudication of competing ideas of constitutional meaning is the idea that courts should be bound by an intellectual discipline that controls judicial discretion. One version of this discipline in making decisions, particularly decisions interpreting constitutional texts, is that judges should seek to fulfil the discernible general purposes that lie behind constitutional provisions; courts should apply these legal texts in ways that advance the purposes that animated their formation. This pro- 
cess can call for constitutional theorizing that converts simple grants of governmental power to broad ideas about democratic power and legitimacy. An example of this process can be found in the decision in Edwards $v$ Attorney General of Canada $^{26}$ (the Persons case) that women can be appointed to the Senate. That decision was based not on finding the one true and essential semantic value of the word "person," 27 but on the basic tenet of responsible government that informs our democratic system - that electors are political governors and that changing who it is that can be an elector must change who it is that is qualified to be a governor or, in the context of responsible government, who it is that can serve as a legislator. This discovery of underlying purpose permitted interpretive dynamism to meet new social realities and sustained the integrity of a fundamental constitutional idea without creating the sense that the language of the constitution is infinitely malleable.

The view that courts are held in check by their obligation to ascribe to texts only meanings that accord with the principles that the textual provisions support is reflected in a many cases decided under the Charter. We can take from the text of the Charter that Canadian constitutional principles are that the state must act in recognition of a universal entitlement to be treated with equal dignity, must guarantee fair and just treatment for all, and must preserve individuals' liberty to pursue personal hallmarks of purpose and identity. These principles are laudable in a free society, but their points of application are often conflicted and controversial. These principles cannot stand on their own terms, as justifications for specific constitutional applications. It would, however, be rash to say that the principles that lie behind Canada's human rights regime should not serve as decisional guides; broad state principles serve effectively both to extend and to constrain judges' applications of legal texts.

In discovering constitutional meaning, broad constitutional ideas such as the prohibition of cruel and unusual punishment, or principles of fundamental justice or equality before the law, represent unequivocal moral values of governing. In order for these moral values to be realized at the point of judicial control of government regulation resort will need to be made to the current moral climate. The ideals of liberty, due process, just treatment and equality must, of course, fit with the needs for social solidarity and common morality, as well as with traditions and principles of public ordering. What is clear is that this boundary between society's needs for order and social solidarity and the precepts of just and fair treatment is always in a state of flux - is always ripe for re-negotiation. What is essential to the idea of constitutional law is that setting this boundary is not a majoritarian task. It is to be conducted under the constitutional understanding that in setting the legitimate borders of respect for personal integrity, majorities are suspect and that constitutional precepts about personal worth and integrity are moral limits to the state's will - a limit that must be determined independently of majoritarian preferences and political urges. The constraint of political morality grants to judges the task of assessing limits with respect to regulation that touches on core elements of personal liberty and dignity, such as who may marry, when state punishment can be imposed, when people can solicit aid in dying, and when segregation and discrimination on the bases of race religion or gender can be resisted. The factors of resolution are constitutionally prescribed but the judgment is rooted in context.

This description of constitutional decisionmaking relies on a dynamic conception of just treatment ice and, hence, a dynamic sense of the scope of constitutional protections. In a sense this idea of constitutional interpretation merely grants courts the usual privilege of interpretation, where judges can set the meaning of a text and give normative weight to the values and (moral) purposes the text suggests. However, this idea of how constitutionalism works within liberal democracy is not universally held. Some feel that the constitutional texts dealing with human rights are so indeterminate in application that there needs to be some rule that constrains judicial interpretation. Otherwise, judges are given too much power to shape the terms of public ordering; democratic theory, they say, requires a high level of judicial boundedness. The question is how to get that degree of boundedness. 
One strategy may be to urge a general attitude of judicial deference to the current decisions of governments and legislatures. ${ }^{28}$

A different strategy for creating judicial boundedness is to infer, or calculate, the constitutional framers' fixed intentions with respect to the text's application. These are characterized as the text's "original intent" and, it is argued, judges should be bound to interpretations of the constitution that correspond to this original intent. ${ }^{29}$ These several approaches to interpretation are common themes of constitutional jurisprudence. They are the ideas that shape a nation's constitutional law. Political accountability for Supreme Court appointments ought to include an understanding by legislators of the nature of constitutional adjudication and its competing theories and ought to include an opportunity for them to demand from persons nominated for appointment nominees' explanations and justifications for their interpretive commitments.

A difficult question may be whether a legislative hearing process conducted by members of the national Parliament - members who, most definitely, are not restricted to legislators who are lawyers - would actually be effective in getting at the central questions relating to a nominee's capacity to sit on the Supreme Court. Capacity for this role should include not only professional capacity as a lawyer (that is, to know law, to know how to find law, to understand normal legal constraints on the interpretation of laws), but also the ability to articulate their understanding of the ethic, purposes and commitments that have shaped the Canadian constitutional order, and should shape it. This inquiry should explore the nominee's ideas about the political virtues of constitutionalism, about the very ethic of constitutionalism. These are not simple enquiries.

Peter Hogg, in responding to the argument that the purposes of a legislative hearing should include questions of judicial philosophy, wrote: "a parliamentary committee is composed of people of various backgrounds and interests, many of them without a sophisticated understanding of constitutional law, and it would not necessarily occur to them that these questions were a valuable way of assessing credentials for a Supreme
Court appointment." 30 However, in democratic elections we ask candidates to speak to their values and commitments and to identify the ends for which they are seeking to exercise power. We ask politicians to relate their political ambition and their political judgment to an idea of the good state that they are willing and able to articulate. It seems likely that legislators are able to explore the positive connection between fitness to hold a state office, such as judge of the Supreme Court of Canada, and the purposes behind its creation. It further seems likely that legislators will understand the connection between a power of adjudication that is constitutionally created and the method, attitudes, and commitments appropriate for its exercise. Institutional arrangements and the talents and attitudes necessary to have their purposes and virtues realized is a fundamental connection, one that legislators understand as well as anyone.

\section{Conclusion}

Justifications for legislative hearings relating to the suitability of a nominee's appointment to the Supreme Court include: first, guaranteeing consideration of actual legal and constitutional commitments, as opposed to loyalty to political or partisan interests; second, the creation of a sense of political ownership over the process of preserving constitutional integrity through judicial review of executive and legislative action; and, third, providing public (and, of course, parliamentary) education about the subtlety of judicial decision-making - its refined elaborations of current normative meaning from antecedent texts designed to produce sound and just ordering. It is true that for these purposes to be realized hard questions relating to nominees' jurisprudential bearings will need to be asked. But law is not that far away from exegesis and interpretation and the constant construction of institutional and personal purposes, based on experience and reflection, that is found everywhere in life - in religion, in history, in ethics, in building houses, in protecting the vulnerable, in promoting valued ends in commerce and in civil society. Parliamentarians deserve to be trusted to think deeply, especially when the nature of the respon- 
sibility that judges bear is explained and when they come to see the nature of the responsibility they bear.

\section{Endnotes}

* Professor Emeritus, Faculty of Law, Queen's University. This essay is adapted from a paper presented to The State of Canada's Constitutional Democracy, a symposium presented by the Asper Centre for Constitutional Rights, University of Toronto and the Centre for Constitutional Studies, University of Alberta, Toronto, February 26-27, 2016.

1 Canada's uneven experiment with legislative hearings of persons named by the federal government for appointment to the Supreme Court from 2006 to 2014 was based on the creation of ad hoc committees of the House of Commons. However, parliamentary review of nominees need not be performed by members of the House of Commons exclusively. Conducting a review through a committee of the Senate or a joint committee of the Senate and the House of Commons may be more effective in establishing a non-partisan deliberation process independent of government interests.

2 This paper was prepared prior to Prime Minister Trudeau's announcement of a new process for appointing judges to the Supreme Court of Canada, beginning with the appointment in the Fall of 2016 of a judge to replace Justice Thomas A. Cromwell who retired on August 30, 2016. See Office of the Prime Minister, "Prime Minister Announces New Supreme Court of Canada Judicial Appointment Process", (Ottawa: Office of the Prime Minister, 2 August 2016), online: <pm.gc.ca/eng/news/2016/08/02/primeminister-announces-new-supreme-court-canadajudicial-appointments-process $>$. The new process will include two opportunities for Members of Parliament and Senators to participate in the appointments process including having the nominee for appointment take part in a moderated question and answer session with members of the House of Commons Standing Committee on Justice and Human Rights, the Standing Senate Committee on Legal and Constitutional Affairs, and others.
3 Although this paper deals only with parliamentary review of nominees for appointment to the Supreme Court, there are other forms of coordinated decision-making with respect to making judicial appointments. One such structure is the creation of a commission that would review the suitability for appointment of persons who apply, or who are proposed, for judicial appointment. Reviews would be based on criteria such as knowledge of law and legal process and character and demeanor. The goal of this mechanism is to restrict judicial appointments to persons who have been assessed as suitable and competent for judicial appointment by a body designed to be non-partisan and expert regarding the judicial function. Such a mechanism has now been adopted by the Government of Canada. See, Office of the Prime Minister, ibid. The new process allows any person qualified for appointment to apply. A seven member Advisory Board will submit to the Prime Minister a shortlist of three to five persons from the list of applicants who it considers suitable for appointment. The Prime Minister's statement on Supreme Court appointments states that this is designed to introduce "an open, transparent and non-partisan process that will help ensure the best, most wellqualified people reflective of Canadian society are named to Canada's top court": ibid.

$4 C f$ Peter W Hogg, "Appointment of Thomas A Cromwell to the Supreme Court of Canada" in Nadia Verrelli, ed, The Democratic Dilemma: Reforming Canada's Supreme Court (Montreal \& Kingston: McGill-Queen's University Press \& Institute of Intergovernmental Relations School of Policy Studies, 2013) 13. Hogg notes that "it is worth remembering that the majority of the court's case load is non-constitutional law": ibid at 24 . This statement was made in response to the claim advanced in John D Whyte, "The Supreme Court from the Outside" (2006) 13 Policy Dialogue 14 that it would be understandable and appropriate if legislators reviewing the suitability of a nominee to the Supreme Court focused their questions on the candidate's approach to constitutional interpretation.

5 Formally, appointments to the Supreme Court of Canada are made by the Governor in Council. They are made by the Governor General on the advice of the Cabinet. See Supreme Court Act, RSC 1985, c S-26, s 4(2).

6 See Graeme G Mitchell, "Say 'Yes' to Advice and Consent: A Reply to Bryan Williams" (1992) 50:6 The Advocate 891. Mitchell states "I cannot share [the] view that the Court, let alone the country, 
will be best served if the choice of its judges resides solely with the Prime Minister with ... assistance from a handful of members of the legal profession": ibid at 897.

7 Part I of the Constitution Act, 1982, being Schedule B of Canada Act 1982 (UK), 1982, c 11.

8 See Robert J Sharpe \& Kent Roach, The Charter of Rights and Freedoms, 4th ed (Toronto: Irwin Law, 2009). Sharpe and Roach say "[u]nder the Charter, the questions put to judges involve issues of value and moral choice, which are not only more openended and apparently less constrained by strict legal principles, but also of greater significance to the average citizen than those relating to federalism": ibid at 27.

9 See Patrick Monahan, Politics and the Constitution: The Charter, Federalism and the Supreme Court of Canada (Toronto: Carswell, 1987). Monahan states: "[C]onstitutional issues that reach the Supreme Court of Canada are fundamentally and inescapably political. Constitutional argument asks the Court to define who we are as individuals and as a people. Such questions cannot be answered through the application of some specialized or technical brand of expertise. What is demanded are political choices and acts of political will": ibid at iii. See also Christopher P Manfredi, Judicial Power and the Charter: Canada and the Paradox of Liberal Constitutionalism (Toronto: Oxford University Press, 2001).

10 See David Schneiderman, Red, White and Kind of Blue?: The Conservatives and the Americanization of Canadian Constitutional Culture (Toronto: University of Toronto Press, 2015) 235-236. Schneiderman writes "While the judiciary has been policing constitutional limits between the federal and provincial governments since Confederation, the entrenchment of constitutional rights has dramatically increased the judicial role in Canadian public life": ibid at 236.

11 Dr. Bonham's Case (1610), 8 Co Rep 107a, 77 ER 646 at 652: ("when an Act of Parliament is against common right or reason, or repugnant, or impossible to be performed, the common law will controul it, and adjudge such Act to be void."

12 Marbury v Madison, 5 US (1 Cranch) 137 (1803). Marshall CJ stated: "Certainly all those who have framed written Constitutions contemplate them as forming the fundamental and paramount law of the nation, and consequently the theory of every such government must be that an act of the legislature repugnant to the Constitution is void. This theory is essentially attached to a written Constitution, and is consequently to be considered by this Court as one of the fundamental principles of our society." ibid at 177 .

13 (1868), 12 NBR 556 (SC).

1428 \& 29 Vict., c 63, s 2 (UK).

15 See Barry L Strayer, The Canadian Constitution and the Courts: The Function and Scope of Judicial Review, 2nd ed (Toronto: Butterworths, 1983) at 20-23 and Gordon Bale, "The New Brunswick Origin of Canadian Judicial Review" (1991) 40 UNBLJ 100.

16 See e.g. Bora Laskin, "Peace, Order and Good Government' Re-examined” (1947), 25:10 Can Bar Rev 1054. Academic debate over the "correctness" of the constitutional interpretations of the Judicial Committee of the Privy Council and the Supreme Court of Canada has been consistently active. An overview of this discussion is found at Peter W Hogg \& Wade K Wright, "Canadian Federalism, the Privy Council and the Supreme Court of Canada: Reflections on the Debate About Canadian Federalism" (2005), 38:2 UBC L Rev 329.

17 See e.g. Canadian Industrial Gas \& Oil Ltd v Government of Saskatchewan, [1979] 1 SCR 37, 91 DLR (3d) 555; Central Canada Potash Co v Government of Saskatchewan, [1979] 1 SCR 42, 91 DLR (3d) 609. Political reaction to these decisions is described in John D Whyte, "A Constitutional Perspective on Federal-Provincial Sharing of Revenues from Natural Resources" in Charles E McLure \& Peter Mieszkowski, eds, Fiscal Federalism and the Taxation of Natural Resources (Lexington, Mass: Lexington Books, 1983) 205-13.

18 See Strayer, supra note 15, where Strayer states: "Though Macdonald did not deal directly with the question of judicial review ... excerpts [from Parliamentary Debates on the Subject of Confederation $8^{\text {th }}$ Parl, $3^{\text {rd }}$ sess at 33] suggest that he did not consider that any 'serious conflict of jurisdiction or authority' would arise": ibid at 17.

19 Constitution Act, 1867 (UK), 30 \& 31 Vict, c 3, s 96, reprinted in RSC 1985, Appendix II, No 5. Appointments are made by the Governor General (impliedly on the advice of the Cabinet).

20 This claim is explored (with skepticism) in Nadia Verrelli, "Reforming the SCC: Rethinking Legitimacy and the Appointment Process" in Verrelli, supra note 4 at 113.

21 See Schneiderman, supra note 10 , ch 5 for a description of the five instances of parliamentary hearings of persons named to the Supreme Court.

22 The House of Commons committee hearings held in respect of five persons named for appointment did not lead to engagement with issues of judicial 
philosophy - or with constitutional theory or principles - and, therefore, did not produce evidence of public interest in, or engagement with, the intellectual process of making judicial decisions. See Michael Plaxton, "The Neutrality Thesis and the Rothstein Hearing" (2008) 58 UNBLJ 92 at 99, where Plaxton states: "[T]here was a remarkable failure to push Justice Rothstein to say anything about how judges go about interpreting broad, open-ended rules" These hearings did, however, give rise to a considerable degree of public media coverage" See also Schneiderman, supra note 10.

23 Hogg, supra note 4.

24 Ibid at 24.

25 Lawrence Sager, "The Domain of Constitutional Justice" in Larry Alexander, ed, Constitutionalism: Philosophical Foundations (Cambridge: Cambridge University Press, 2001) 235. Sager states: "[C] onstitutional justice has a domain - a general area of concern that can be described with sufficient clarity to aid in understanding the Constitution generally and in resolving specific problems of interpretation.": ibid at 235.

26 [1929] UKPC 86, [1930] AC 124.

27 Constitution Act, 1867, supra note 19, s 24 provides: "The Governor General shall ... summon qualified persons to the Senate."

28 There is nothing in the concept of democracy that suggests that contemporary ideas of good governmental action should take priority over other, older and more procedural, ideas of good governance that have themselves been chosen through a democratic process (although, as ideas of self-government change, possibly a less inclusive democratic process). Current popular support is not intrinsically a more legitimate form of self-determination than following the ideas and principles of governance that have been adopted by "the people" at a prior time. It should be within the range of popular self-determination to create long-term rules of governance. See Bruce Ackerman, We the People: Foundations, vol I (Cambridge: Belknap Press, 1991) at 3-33.

29 The process of recovering the drafters' intentions is as much dogged by uncertainty as interpreting the words that they used to express their ideas. More to the point, to decide that what the drafters intended on the basis of what we think they thought about (often unanticipated) social practices would be a faulty assumption in that it excludes, without reason, their more likely intention to create an on-going interpretive community - that they intended to assign responsibility for the meaning of the text to the future generations of judges who would dwell among the people who would be bound by the their decisions. See H Jefferson Powell, "The Original Understanding of Original Intent" (1985) 98:5 Harv L Rev 885. In fact, what can ever be the true reality of interpretation other than taking on board the world that lives beyond the text and seeking the integration of the text's ideas with our experience and our knowledge? How else do humans ever reconcile themselves with their history and memory?

30 Hogg, supra note 4, at 24. 